\title{
Article
}

\section{Nanotechnology applied to European food production - A review of ethical and regulatory issues}

Coles, David and Frewer, L.J.

Available at http://clok.uclan.ac.uk/11756/

Coles, David ORCID: 0000-0003-4774-4800 and Frewer, L.J. (2013)

Nanotechnology applied to European food production - A review of ethical and regulatory issues. Trends in Food Science \& Technology, 34 (1). pp. 32-43.

ISSN 09242244

It is advisable to refer to the publisher's version if you intend to cite from the work.

http://dx.doi.org/10.1016/j.tifs.2013.08.006

For more information about UCLan's research in this area go to http://www.uclan.ac.uk/researchgroups/ and search for < name of research Group>.

For information about Research generally at UCLan please go to http://www.uclan.ac.uk/research/

All outputs in CLoK are protected by Intellectual Property Rights law, including Copyright law. Copyright, IPR and Moral Rights for the works on this site are retained by the individual authors and/or other copyright owners. Terms and conditions for use of this material are defined in the policies page.

\section{CLoK}

Central Lancashire online Knowledge www.clok.uclan.ac.uk

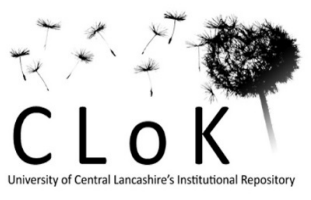




\section{Review}

Nanotechnology applied to European
food production - A review of ethical and regulatory issues

\author{
D. Coles* and L.J. Frewer
}

Food and Society Group, School of Agriculture, Food and Rural Development, Newcastle University, Newcastle Upon Tyne NE1 7RU, United Kingdom (Tel.: +44 (0)191 222 8272; e-mail: David.Coles2@ newcastle.ac.uk)

Various ethical issues are associated with agrifood nanotechnology, linked to the ethical concepts of autonomy, beneficence, non-malfeasance and justice (ensuring safety, effective risk assessment, transparency, consumer benefits and choice, animal welfare and environmental protection). Nanotechnology applications are currently covered by legislative instruments originally designed for other purposes. Risk assessment procedures are in most cases not specific to (agrifood) nano-materials, resulting in uncertainty regarding the nature and extent of potential risks. There are currently no requirements for nano-materials used in agrifood production to be labelled. Ethical principles, and societal acceptance require labelling of food products that are produced using nanotechnology.

\section{Introduction}

All new technologies have the potential to raise ethical issues and generate ethical concerns amongst stakeholders, although whether or not this occurs is contingent on characteristics of the technology in question (e.g. see Beck, 1992; Frewer, Bergmann, et al., 2011; Frewer, Norde, Fisher, \& Kampers, 2011; Hoban, 1997). Key issues, which are relevant to discussion of ethics, food and new

\section{* Corresponding author.}

0924-2244/\$ - see front matter (C) 2013 Elsevier Ltd. All rights reserved. http://dx.doi.org/10.1016/j.tifs.2013.08.006 technologies are food safety, risks and benefits (to human health, the environment, and in terms of socio-economic impacts), and consumer choice. The extent to which the benefits (and risks if any) are equitably distributed (for example, across food producers in different countries, or between producers and consumers) is relevant. These can be considered from an ethical perspective in the way in which they impinge on fundamental ethical principles of non-malfeasance, beneficence, autonomy and justice.

The aim of this review is to provide an analysis of potential ethical and regulatory issues associated with current and future potential food and agriculture related applications of nanotechnology.

\section{Developments in nanotechnology and food}

Nanotechnology is the manufacture and use of materials and structures at the nanometre scale (a nanometre is one millionth of a millimetre). Many large scale manufacturers of foods and agricultural products have already invested heavily in nanotechnology R\&D (Scrinis and Lyons 2007) and nanotechnology is already being used in some countries in the production of agricultural products, processed foods and drinks, and in food packaging. There is currently little regulation that relates specifically to applications of nanotechnology in any field of application, and particularly in relation to food. Regulators therefore rely instead on a range of other relevant current regulations designed principally with applications other than nanotechnology in mind. This approach is set out in the European Commission Recommendation of $07 / 02 / 2008$ on a code of conduct for responsible nanosciences and nanotechnologies research. The relevant European regulations that need to be considered extends from REACH (the EC Regulation No. 1907/2006 on Chemicals, aimed at preventing harm to humans or the environment), through the Waste Framework Directive 2008/98/EC to the Novel Foods Regulation (EC) No. 258/97) (Table 1).

Nanotechnology is used in a wide range of food-related applications (Frewer, Norde, et al., 2011) but there is no definitive list of foods or food contact products that involve nanotechnology and it is difficult to estimate how widespread is the use of nanotechnology in food and agriculture (Jones, House of Lords Evidence 2009). In contrast, other industries have been forced to provide very specific information on nanomaterials that are included in their products. For example, Article 16 of the recently enacted European 


\begin{tabular}{|c|c|c|}
\hline Regulatory instrument & Title & Purpose \\
\hline REACH & $\begin{array}{l}\text { Regulation (EC) No 1907/2006 on } \\
\text { Chemicals }\end{array}$ & $\begin{array}{l}\text { Emphasis on preventing harm to humans or the } \\
\text { environment (precautionary approach) }\end{array}$ \\
\hline Health and Safety Directive & $\begin{array}{l}\text { Safety and Health of Workers } \\
\text { Directive 89/391/EE }\end{array}$ & $\begin{array}{l}\text { Regulation of exposure of workers to potentially } \\
\text { hazardous substances }\end{array}$ \\
\hline Novel Foods Regulation & EC Regulation 258/97 & $\begin{array}{l}\text { Approval required to ensure food products made } \\
\text { with nanotechnology are safe. }\end{array}$ \\
\hline $\begin{array}{l}\text { General obligation to provide } \\
\text { safe food }\end{array}$ & EC Regulation 178/2002 & $\begin{array}{l}\text { Lays down the general principles governing food and } \\
\text { feed in general, and food and feed safety in } \\
\text { particular, at Community and national level. }\end{array}$ \\
\hline General Product Safety Directive & Directive 2001/95/EC & $\begin{array}{l}\text { A general product safety requirement, containing } \\
\text { provisions on the general obligations of producers } \\
\text { and distributors, and on the enforcement of } \\
\text { Community product safety requirements to ensure } \\
\text { consumers safety and health. }\end{array}$ \\
\hline The IPPC Directive & EU Council Directive 2008/1/EC & $\begin{array}{l}\text { Relates to Integrated Pollution Prevention and } \\
\text { Control (IPPC) in respect of release of pollutants into } \\
\text { the environment. }\end{array}$ \\
\hline The Seveso II Directive & Directive 96/82/EC & Prevention and control of chemical accidents. \\
\hline The Water Framework Directive & Directive 2000/60/EC & $\begin{array}{l}\text { Protects rivers, lakes, estuaries, coastal waters, } \\
\text { groundwater and ecosystems in relation to their } \\
\text { water needs; promotes sustainable water and } \\
\text { progressive reduction of pollution of groundwater, } \\
\text { reduction of discharges, emissions and leaching of } \\
\text { hazardous substances. }\end{array}$ \\
\hline Waste Framework Directive & Directive 2008/98/EC & $\begin{array}{l}\text { Lays down measures to protect the environment and } \\
\text { human health by preventing or reducing the adverse } \\
\text { impacts of the generation and management of waste } \\
\text { and by reducing overall impacts of resource use and } \\
\text { improving the efficiency of such use. }\end{array}$ \\
\hline $\begin{array}{l}\text { EC Communication on } \\
\text { Regulatory Aspects of } \\
\text { Nanomaterials }\end{array}$ & COM (2008) 366 final & $\begin{array}{l}\text { Promotes an integrated, safe and responsible } \\
\text { approach to use of nanotechnology and ensures that } \\
\text { applications and use of nanosciences and } \\
\text { nanotechnologies comply with the high level of } \\
\text { public health, safety, consumer and worker } \\
\text { protection, and environmental protection }\end{array}$ \\
\hline
\end{tabular}

Cosmetics Regulation (Regulation (EC) 1223/2009) ${ }^{1}$ outlines specific requirements related to nanomaterials in cosmetics. Notably, by January 11, 2014, the Commission will make publicly available a catalogue of all nanomaterials used in cosmetic products that have been placed on the market. Moreover, the Regulation states that for cosmetic products that contain nanomaterial ingredients, the names of any such ingredients must be clearly indicated in the ingredient list followed by the word "nano" in brackets. This openness and transparency that is required by cosmetics regulators is in contrast to the apparent lack of requirements of the food regulators, at least at time of writing. However, it is possible to identify key areas of nanotechnology application to food and agriculture.

\section{Agricultural practice}

There has been significant investment in agricultural applications of nanotechnology which are largely intended to

\footnotetext{
${ }^{1}$ http://eur-lex.europa.eu/LexUriServ/LexUriServ.do?uri=CELEX: 32009R1223:EN:NOT (accessed 22nd August 2013).
}

address some of the limitations and challenges facing largescale, chemical and capital intensive farming systems (Scrinis \& Lyons, 2007). Objectives include improvement of the efficiency of soils and other growing media and facilitating targeted delivery of both nutrients and pesticides. Specific current and potential applications designed to improve the fertility and capacity of soil and other growth substrates, include the fine tuning and more precise micromanagement of soils, more efficient and targeted use of inputs such as fertilisers and other soil additives (Scrinis and Lyons, 2007), and use of nano-iron and carbon nanotubes for soil and water remediation and purification (Karn, Kuiken, \& Otto, 2009). New substances are also being formulated for more effective pest control, including smart pesticides, some of which would have the capacity to respond differentially to a range of pests including targeted action through smart sensors and smart delivery nanosystems (Rai \& Ingle, 2012). The incorporation of nanosensors into livestock may facilitate animal tracking, drug-delivery systems or detection presence of certain substances such as drugs, growth hormones etc. when animals are marketed (Nguyen, Ngo, \& Nguyen, 2012). The 
encapsulated vaccine is released into the water but only released from the micro-capsule once ingested by the fish (Nielsen, Fredriksen, \& Myhr, 2011). Research on the nano-modification of seeds (precision GM) has the potential to enable very precise genetic modification of seeds (Scrinis and Lyons, 2007), and could potentially be extended to animals.

\section{Food manufacture and processing}

Nano-sieves are already in use for nanofiltration applications in the manufacture and preparation of food (Erikkson, 1988). Nano-materials have been applied to create nonfouling surfaces in food preparation which prevents clogging of processing machines and reduces the need for both cleaning and machine downtime, lowering production costs (Tepper et al., 2005 Patent) Fibrillar protein aggregates are being developed as meat replacers, and nanotechnology may be one route to enable fibrillar proteins to be constructed to imitate meat (Norde, 2011). Nanotechnology can also improve the texture of foods (e.g. improving texture of dairy products such as yogurts and ice-cream) (Khan, 2012).

\section{Food packaging}

The application of nanotechnology to food packaging has been introduced to improve mechanical and barrier properties. Packaging applications includes use of nanosilver as a microbicide to extend the freshness of food and prevent contamination (Duncan; 2011; Maillard \& Hartemann, 2012). Nano-materials can also be used to improve the packaging barrier properties to regulate the passage of gases and moisture through the packaging to extend shelf life and maintain quality and freshness (Sozer \& Kokini, 2009). Improved biodegradability of packaging (Sozer \& Kokini, 2009), and stronger, less bulky packaging, developed through nanotechnology, could generate less waste. Nanosensors are under development to detect both the ripeness of packaged products and also the presence of pathogens (Kuswandi et al., 2011). These are likely to be in the form of "buttons" on the packaging which change colour. This approach could also be used to signal whether the packaged food is displayed or stored in optimum environmental conditions.

\section{Food products, supplements and additives}

Nano-encapsulation (where ingredients are encapsulated in a nano-material that protects it from gut digestive juices until it reaches its target which it identifies by surface interaction) and increased bioactiviation (where a nanosubstrate can be used to optimise the way a bioactive ingredient is presented to its target) are important elements in the development of novel foodstuffs, particularly functional foods and nutriceuticals for the delivery of drugs to specific sites or for oral vaccines (Kaufmann, 2005; Pandey, Ahmad, Sharma, \& Khuller, 2005). Increased bioavailability through nanocrystals would enable e.g. omega- 3 fatty acids, phytosterols, flavours, antimicrobial components, antioxidants and carotenoids such as $\beta$-carotene and lycopene to be absorbed more effectively where they are needed (Graciela, 2012). Nano-encapsulation could also reduce the uptake of (e.g.) fats, thus allowing delivery of the flavour of fats without their calorific or other undesirable effects. Nano-enabled modified flavour delivery may result in nonfatty foods tasting fatty (Chaudhry, Castle, \& Watkins, 2010).

Delivery systems for biologically active compounds are already available. For example, in Germany nanotechnology is used in foods and dietary supplements to produce inter alia, nano-green tea, to improve the bioavailability of selenium from the leaves, "Canola Active" cooking oil with microencapsulate phytosterols to reduce absorption of cholesterol, nano-vitamins and nano-coenzymes (Sekhon, 2010).

\section{Potential risks of nanotechnology}

As particles approach the nano-scale, their properties can change, which can have highly unpredictable impacts on humans, other animals and the environment. Some nanoparticles can cross biological barriers, including across the blood-brain barrier, and thus potentially have the ability to enter cells and organs. As a consequence there is potential for these to interact with normal biological processes in an unpredictable manner (Leroueil et al., 2007). Little work has been conducted on risk assessment specifically directed at nano-materials, and it is not known how the human body responds to these chemicals. The evidence for health risks associated with ultrafine and nanoparticles after inhalation has been increasing (Kreyling, Semmler-Behnke, \& Moller, 2006; Penyala, Pena-Mendez, \& Havel, 2008). There is the possibility that nano-materials such as nano-silver may bioaccumulate in food (from nano-packaging or from accumulation in plants and animals used in food production), or in the human body (Pronk et al., 2009). The wide range of activity and use of nanomaterials, including their properties as microbicides, pesticides and activation catalysts, results in potentially real and unknown risks being associated with their use. This is particularly relevant because of the lack of nano-related risk and toxicity assessments. Risk assessment (RA) procedures used in other related regulatory instruments may not always be appropriate for the special characteristics of many nano-materials (Oberdörster, 2010; O’Brien \& Cummins, 2008).

Nanomaterials may also result in a significant risk to the environment (Klaine et al., 2008). Use of nano-silver in packaging could lead, during waste disposal, to its leaching and accumulation into the environment where it would continue to kill micro-organisms, resulting in problems for water treatment installations and for other microbial activity in the environment (Fabrega, Luoma, Tyler, Galloway, \& Lead, 2011). Use of nano-iron and carbon nanotubes in the remediation of soils involves putting them directly into the environment and while it is not clear how fixed they would be to the soil being treated, the soil itself would be subject to movement through the 
environment with the consequent accumulation of the nanomaterials in other areas including water courses (Boxall, Tiede, \& Chaudhry, 2007). Some studies (Poland et al., 2008), have suggested that carbon nanotubes could have similar human heath-impact properties to asbestos. While results from inhalation studies in particular are much more mixed, it is clear that there is on-going uncertainty about toxic levels of exposure particularly through inhalation, both for carbon nanotubes and also carbon fibres (DeLorme et al., 2012; Ryman-Rasmussen et al., 2009). Carbon nanotubes are in the process of being incorporated into some packaging materials to detect microorganisms, toxic proteins and food spoilage (ElAmin, 2007; Wang, Zhao, et al., 2011; Wang, Zhu, Zhang, Zhao, \& Liu, 2011). One of the rationales for the use of nano-particle pesticide applications lies in their improved capacity for absorption into plants compared to larger particles. As such, while they may not be washed off as readily, thereby increasing their effectiveness, this does pose a new order of risks to consumers of treated plants as the pesticides would consequently be more persistent on the plant. Farm workers and rural residents are being exposed to these nano-pesticides without any requirement for safety testing or regulation of nano-scale formulations of already approved chemical pesticides (Lyons \& Scrinis, 2009). The size and dissolvability of nanoparticle pesticides may also mean they contaminate soils, waterways and food chains across a wider geographical area, while nanoencapsulated pesticides may release their toxins in other environments or in the stomachs of other living organisms (Chaudhry et al., 2010; Scrinis \& Lyons 2007). There is evidence which may suggest that exposure to nanoparticles (Titanium oxide) reduces reproductive output in zebrafish, and causes damage to the gills of trout (Federici, Shaw, \& Handy, 2007; Wang, Zhao, et al., 2011; Wang, Zhu, et al., 2011). Nano-encapsulated vaccinations of fish involve release of the nanoparticles carrying the vaccine into open or semi-open aquatic systems where their dispersal patterns and subsequent destination is likely to be unpredictable.

While nanotechnology is increasingly used in food manufacture, very little work has been done to assess the risk of contamination of food products with nanomaterials used in processing such as nano-filtration, nonfouling surfaces, or catalytic processes. Risks associated with use of nanotechnology to improve texture in food products appear not to have been assessed. Where nanotechnology is incorporated in food products for use in the European Union, these have to comply with the EC Regulation on Novel Foods. This would apply to the use of nanoencapsulation, increasing bio-activation and bio-availability products that currently incorporate nanotechnology.

\section{Regulation of nanotechnology}

There are currently no specific regulations on food nanotechnology applications either in Europe or elsewhere, in part because of the diversity of these applications. Within Europe, nanotechnology applications, including those related to food, are deemed to be covered by existing legislation. As a result there are a large number of regulations that may need to be taken into account (Table 1). There is also a requirement to assess whether the existing regulation needs to be modified for nanotechnology applications (European Commission, 2008a).

The European Commission (2008b, p3) has noted that:

"The regulatory challenge is therefore to ensure that society can benefit from novel applications of nanotechnology, whilst a high level of protection of health, safety and the environment is maintained"

The Commission in 2008 proposed amendments to the regulation on Novel Foods which inter alia includes a legal definition of nano-materials and their mandatory labelling. However the European Council and the European Parliament (EP), have been unable to agree on amending the existing Regulation. The Opinion of the European Food Safety Authority's (EFSA) Scientific Committee on the Potential Risks Arising from Nanoscience and Nanotechnologies on Food and Feed Safety (European Food Safety Authority, 2009) emphasises how little regulation is in place that can readily and appropriately be applied to food-related nanotechnology applications. This situation makes it difficult for developers and manufacturers to know what, if any, regulations should be complied with, and what risk assessments, if any, are appropriate. The increasingly rapid development of nanotechnology applications in this area means that some form of appropriate and consistent governing regulation and assessment is urgently needed (Kreyling et al., 2006).

A number of initiatives have been launched with the objective of establishing a more coherent approach to risk assessment for nanotechnology applications. Examples of such initiatives include: Euro-NANOTOX www.euro-nanotox.at (launched 2007), BioNanoNet; www.euro-nanotox.at (launched 2009) and the OECD-Database on Research into the Safety of Manufactured Nanomaterials http://webnet. oecd.org/NANOMATERIALS (launched 2009). However a coherent standardisation of risk assessment of nanotechnology applications and use is still some way off.

\section{Ethical issues related to nanotechnology and food}

According to a Eurobarometer conducted in 2010, Europeans appear to "know little about nanotechnology, are not excessively concerned about risks and believe nanotechnology should be encouraged" (European Commission, 2012). However, the EuroBarometer asked about nanotechnology in general terms and did not refer to nanotechnology in relation to food. While consumers may approve of a technology in some fields (e.g. medicine) they may be much less approving if it is used in relation to food. This clearly has been the situation in the case of biotechnology 
and genetic modification (e.g. Frewer, Howard, \& Shepherd, 1997). Generally, however, at present most people appear positive towards nanotechnology. For example, a meta-analysis of 22 surveys conducted in Canada, the United States, Europe and Japan between 2002 and 2009 showed that the members of the public who perceive greater benefits outnumber those who perceive greater risks by 3 to 1 (Satterfield, Kandlikar, Beaudrie, Conti, \& Herr Harthorn, 2009) Several authors have suggested that many of the public concerns discussed in the literature on biotechnology in food are being raised in qualitative and quantitative studies on nanotechnologies for food (Mehta, 2004; Rogers-Brown, Shearer, \& Harthorn, 2011), suggesting that some people express concerns about nanotechnological modifications of food. Indeed, experts are of the view that food-related applications of nanotechnology may be the most problematic in terms of societal acceptance (Gupta, Fischer, \& Frewer, 2012; Gupta, Fischer, van der Lans, \& Frewer, 2012). To date the empirical evidence for this is somewhat mixed, in particular in the context of concrete applications with tangible benefits. Fischer, van Dijk, de Jonge, Rowe, and Frewer (2012) found considerable intra-individual variation in attitudes to food-related nanotechnology after the provision of balanced risk-benefit information about risk and benefit. Siegrist, Cousin, Kastenholz, and Wiek (2007) report that consumer acceptance is high for food-related applications with concrete and tangible benefits. However, consumers may not be aware of the extent to which nanotechnology is already applied in agriculture and the manufacture and supply of food products, nor the potential risks and the limited extent to which these are currently assessed. It is tempting to again draw a cautionary parallel with the situation of GM food products at the very end of the 20th century (Kearnes et al., 2006) when a number of products were already available for sale to consumers but little or no information had been provided on potential risks, nor was consideration given to how consumers might benefit from the incorporation of GM ingredients into foodstuffs.

There has been some discussion about how relevant it is to apply ethical considerations to nanotechnology. The general consensus appears to be that nanotechnology does not constitute a "special case" for ethical consideration but that the normal ethical analysis approach of autonomy, nonmalfeasance, beneficence and justice can be effectively applied to nanotechnology issues (Ebbesen, Andersen, \& Besenbacher, 2006; Kuzma \& Besley, 2008).

It is useful to apply an Ethical Matrix analysis (Mepham, 2000) to the broad categories of application of nanotechnology to see how the ethical principles of autonomy (self-determination), non-malfeasance (no harm), beneficence ("do good") and justice (fairness) apply to different stakeholders, animals and the environment (See Table 2). While this has limitations in analysing and weighing the ethical issues associated with a technology, it is helpful in identifying the types of issues that may need to be considered (Schroeder \& Palmer, 2003). A more detailed analysis could be carried out on individual applications which might represent a useful inclusion in the risk assessment process.

The most prominent area of ethical concern for nanotechnology as it impacts on food and agriculture is that of non-malfeasance ('do no harm') i.e. the safety of the food or process. This is particularly important because of the level of unknown risk associated with this technology and the potential for unforeseen consequences to humans, biological organisms and the environment, including risks to future generations. The extensive range of potential applications of nanotechnology, and the fact that the European Commission and its associated bodies such as EFSA also acknowledge that existing regulatory instruments and risk assessment processes are not wholly appropriate and may need to be modified for nanotechnology applications, possibly on a case by case basis, is another factor indicating the need for a cautionary, and possibly a precautionary approach to implementation of nanotechnology innovations in food and agriculture in particular.

There are a large number of claims about the ability of nanotechnology applied to food and agriculture to "do good" (beneficence) and there does appear to be evidence that nanotechnology has the potential for significant benefits from "Farm to Fork". However, these claims cannot justify the use of nanotechnology applications without some understanding of the magnitude and likelihood of any potential risks. Risk/benefit balance is an important ethical consideration. Manufacturers, processors, and producers should ensure that there is minimal risk to endusers and consumers, animals, the environment as well as to future generations. Some degree of risk or potential for harm may however be acceptable if there is an even greater potential for the application to be of benefit (beneficence to 'do good'). However there must be complete transparency and risk/benefit communication about both potential risks and benefits to consumers to enable free and informed choice. From the perspective of the consumer, there is little justification for developing a nano-process if it does not produce a higher quality or less expensive product for consumption. However it might be considered to be justified in situations where it produces much greater quantities of food to promote food security.

The ethical principle of Justice (fairness) requires that where potential for risk exists, there should be fairness in the way in which, and by whom, these risks are borne. Fairness requires that those exposed to such risks should be aware of them. It should also be clear to whom any benefits accrue. Those subjected to the greatest risk should also have the potential to receive the greatest benefit. For example, it would not be ethically just or fair if the benefits of a new technology were enjoyed by the manufacturer while all the risks accrued to the consumer, even if these were very small or uncertain (Frewer, Bergmann, et al., 2011; Frewer, Norde, et al., 2011). There is evidence that 


\begin{tabular}{|c|c|c|c|c|c|}
\hline $\begin{array}{l}\text { Area of } \\
\text { application }\end{array}$ & $\begin{array}{l}\text { Stakeholder/ } \\
\text { Entity }\end{array}$ & Autonomy & Non-malfeasance & Beneficence & Justice \\
\hline \multirow[t]{8}{*}{ Agriculture } & $\begin{array}{l}\text { Nano-Product } \\
\text { developer }\end{array}$ & $\begin{array}{l}\text { Freedom to develop } \\
\text { applications, in compliance } \\
\text { with any applicable regulation }\end{array}$ & $\begin{array}{l}\text { Test for and minimise any } \\
\text { potential harm to other } \\
\text { stakeholders } \\
\text { Avoid exploitation of the } \\
\text { market and warn stakeholders } \\
\text { of any risks. }\end{array}$ & $\begin{array}{l}\text { Increased profit from successful } \\
\text { applications (e.g. financially and/or } \\
\text { in terms of increased scientific } \\
\text { endeavour) }\end{array}$ & $\begin{array}{l}\text { Clear and consistent regulatory } \\
\text { framework and risk assessment } \\
\text { process to facilitate product } \\
\text { development and minimise } \\
\text { uncertainties or risk of market } \\
\text { failure. }\end{array}$ \\
\hline & Farmer & $\begin{array}{l}\text { Evidence-based freedom to } \\
\text { choose whether to adopt the } \\
\text { technology (whether for inputs } \\
\text { or produce) without pressure } \\
\text { from processors or distributors }\end{array}$ & $\begin{array}{l}\text { Responsible use of nano-products } \\
\text { in accordance with regulations } \\
\text { and to avoid harm to animals } \\
\text { or damage to environment } \\
\text { through waste disposal. }\end{array}$ & $\begin{array}{l}\text { Increased profit from improved } \\
\text { products and yields. } \\
\text { Improved and more efficient } \\
\text { farming practice. }\end{array}$ & $\begin{array}{l}\text { Improve welfare of animals and } \\
\text { enhance environmental } \\
\text { sustainability }\end{array}$ \\
\hline & Processor & $\begin{array}{l}\text { Freedom to choose whether } \\
\text { to select raw materials and } \\
\text { processes that make use of } \\
\text { nanotechnology }\end{array}$ & $\begin{array}{l}\text { Avoid use of supplies that have } \\
\text { caused harm to animals and their } \\
\text { welfare or to the environment. } \\
\text { Ensure that products and processes } \\
\text { are tested to avoid harms to } \\
\text { consumer health or the environment. }\end{array}$ & $\begin{array}{l}\text { Ability to profit from use of } \\
\text { nanotechnology applications } \\
\text { in processing. }\end{array}$ & $\begin{array}{l}\text { Clear and consistent regulatory } \\
\text { framework including safety and } \\
\text { labelling requirements }\end{array}$ \\
\hline & Consumer & $\begin{array}{l}\text { Informed by producers and } \\
\text { distributors when nanotechnology } \\
\text { is used in agricultural processes, } \\
\text { even when not included in the } \\
\text { final product. } \\
\text { Access to sufficient information } \\
\text { to make an informed choice. }\end{array}$ & $\begin{array}{l}\text { Make use of information about the } \\
\text { nature of any nano-materials used } \\
\text { and their production in order to avoid } \\
\text { any risks to health or purchasing } \\
\text { decisions that support poor animal } \\
\text { welfare. Dispose of nano-waste in } \\
\text { a safe and sustainable way }\end{array}$ & $\begin{array}{l}\text { Ability to benefit from better } \\
\text { quality food and greater } \\
\text { health benefits without } \\
\text { fear of unknown risks. }\end{array}$ & $\begin{array}{l}\text { Any potential risks should be } \\
\text { outweighed by potential benefits } \\
\text { for the consumer. Including } \\
\text { socioeconomic risks as well as } \\
\text { health and environmental risks } \\
\text { A clear, consistent and transparen } \\
\text { regulatory framework to provide } \\
\text { assurance of compliance } \\
\text { throughout the food chain. }\end{array}$ \\
\hline & Animals & $\begin{array}{l}\text { Optimum quality of life and } \\
\text { freedom of movement in } \\
\text { primary production. }\end{array}$ & $\begin{array}{l}\text { Animal welfare should not be } \\
\text { reduced by nanotech applications } \\
\text { or their bioaccumulation in the } \\
\text { food chain or agricultural } \\
\text { environment }\end{array}$ & $\begin{array}{l}\text { Improvement in feed and } \\
\text { welfare }\end{array}$ & $\begin{array}{l}\text { Respect and maintenance } \\
\text { of "telos"* (i.e. an animal's } \\
\text { biological nature). }\end{array}$ \\
\hline & Environment & $\begin{array}{l}\text { Maintenance of sustainable } \\
\text { natural environment }\end{array}$ & $\begin{array}{l}\text { Appropriate assessment of } \\
\text { environmental risks and } \\
\text { measures to minimise or } \\
\text { eliminate contamination, } \\
\text { bioaccumulation or leaching } \\
\text { of nano-materials from treated } \\
\text { soils, pesticides or animal } \\
\text { products into the wider } \\
\text { environment }\end{array}$ & $\begin{array}{l}\text { Use of nano-materials to } \\
\text { improve environmental } \\
\text { conditions and promote } \\
\text { sustainability. }\end{array}$ & $\begin{array}{l}\text { Measures in place to prevent } \\
\text { secondary contamination of } \\
\text { other land by migration of } \\
\text { nano-materials. }\end{array}$ \\
\hline & $\begin{array}{l}\text { Future } \\
\text { Generations }\end{array}$ & $\begin{array}{l}\text { Future health and environment } \\
\text { should not be jeopardised by } \\
\text { current use of nanotechnology }\end{array}$ & $\begin{array}{l}\text { Regulatory system should } \\
\text { protect future human health, } \\
\text { environment and animal } \\
\text { welfare including wildlife. }\end{array}$ & $\begin{array}{l}\text { Enhanced environmental } \\
\text { conditions and food production } \\
\text { plus advances in human health } \\
\text { and nutrition and animal } \\
\text { welfare. }\end{array}$ & $\begin{array}{l}\text { Future health and environment } \\
\text { should not be jeopardised by } \\
\text { current use of nanotechnology }\end{array}$ \\
\hline & & & & & (continued on next page \\
\hline
\end{tabular}




\begin{tabular}{|c|c|c|c|c|c|}
\hline $\begin{array}{l}\text { Area of } \\
\text { application }\end{array}$ & $\begin{array}{l}\text { Stakeholder/ } \\
\text { Entity }\end{array}$ & Autonomy & Non-malfeasance & Beneficence & Justice \\
\hline \multirow[t]{7}{*}{$\begin{array}{l}\text { Food } \\
\text { processing }\end{array}$} & $\begin{array}{l}\text { Nano-Product } \\
\text { developer }\end{array}$ & As for agriculture & As for agriculture & As for agriculture & As for agriculture \\
\hline & Farmer & As for agriculture & As for agriculture & $\begin{array}{l}\text { Increased profit from improved } \\
\text { processing of produce to } \\
\text { enhance flavours, delivery } \\
\text { and shelf life., as well as } \\
\text { consumer demand for } \\
\text { products with improved } \\
\text { qualities }\end{array}$ & As for agriculture \\
\hline & Processor & $\begin{array}{l}\text { Access to sufficient } \\
\text { technological information } \\
\text { and risk assessment data } \\
\text { to make appropriate } \\
\text { risk/benefit decisions on } \\
\text { employing nano-based } \\
\text { processing solutions. }\end{array}$ & As for agriculture & $\begin{array}{l}\text { Ability to profit from use } \\
\text { of nanotechnology applications } \\
\text { in processing. } \\
\text { Cleaner more efficient machinery } \\
\text { reduces energy use }\end{array}$ & As for agriculture \\
\hline & Consumer & $\begin{array}{l}\text { Informed by manufacturers } \\
\text { when nanotechnology is } \\
\text { used in foodstuffs and their } \\
\text { processing, and why they } \\
\text { are included. } \\
\text { Access to sufficient } \\
\text { information to make an } \\
\text { informed purchasing choice. }\end{array}$ & As for agriculture & As for agriculture & As for agriculture \\
\hline & Animals & $\begin{array}{l}\text { Optimum quality of life and } \\
\text { freedom of movement } \\
\text { during manufacture and } \\
\text { processing }\end{array}$ & As for agriculture & As for agriculture & As for agriculture \\
\hline & Environment & As for agriculture & As for agriculture & $\begin{array}{l}\text { Protection and promotion } \\
\text { of environmental } \\
\text { sustainability and } \\
\text { prevention of nanotechnology } \\
\text { waste being distributed or } \\
\text { leached into the environment. }\end{array}$ & As for agriculture \\
\hline & Future Generations & As for agriculture & As for agriculture & As for agriculture & As for agriculture \\
\hline \multirow[t]{2}{*}{ Packaging } & $\begin{array}{l}\text { Nano-Product } \\
\text { developer }\end{array}$ & As for agriculture & As for agriculture & As for agriculture & As for agriculture \\
\hline & Farmer & $\begin{array}{l}\text { Freedom to choose whether } \\
\text { to supply produce for use } \\
\text { with nano-packaging or } \\
\text { whether to use input } \\
\text { products (e.g. animal } \\
\text { feeds) supplied in } \\
\text { nano-packaging. }\end{array}$ & As for agriculture & $\begin{array}{l}\text { Improved profits from } \\
\text { (e.g) longer shelf life of } \\
\text { produce or improved quality }\end{array}$ & N/A \\
\hline
\end{tabular}




\begin{tabular}{|c|c|c|c|c|c|}
\hline & Processor & $\begin{array}{l}\text { Freedom to choose } \\
\text { whether to use particular } \\
\text { nanotechnology products } \\
\text { in packaging }\end{array}$ & As for agriculture & $\begin{array}{l}\text { Ability to profit from use } \\
\text { of nanotechnology } \\
\text { applications in packaging. }\end{array}$ & As for agriculture \\
\hline & Consumer & $\begin{array}{l}\text { Packaging should be } \\
\text { labelled to indicate use } \\
\text { of nanomaterials and } \\
\text { identify the specific } \\
\text { nano-product(s) used } \\
\text { together with its purpose } \\
\text { in order that consumers } \\
\text { can make an informed } \\
\text { purchasing choice. }\end{array}$ & $\begin{array}{l}\text { Provide with information } \\
\text { about the nature of any } \\
\text { nano-materials used in } \\
\text { packaging materials, any } \\
\text { risks to health and } \\
\text { information and facilities } \\
\text { to dispose of nano-packaging } \\
\text { materials in a safe and } \\
\text { sustainable way }\end{array}$ & $\begin{array}{l}\text { Ability to benefit from } \\
\text { better quality, longer } \\
\text { lasting food, or improved } \\
\text { food security, without fear } \\
\text { of unknown risks. }\end{array}$ & As for agriculture \\
\hline & Animals & N/A & N/A & N/A & N/A \\
\hline & Environment & $\begin{array}{l}\text { Appropriate disposal } \\
\text { of nano-packaging } \\
\text { materials to ensure } \\
\text { the maintenance of a } \\
\text { sustainable natural } \\
\text { environment. }\end{array}$ & $\begin{array}{l}\text { Appropriate assessment } \\
\text { of environmental risks } \\
\text { and measures in place } \\
\text { to minimise or eliminate } \\
\text { contamination, } \\
\text { bioaccumulation or } \\
\text { leaching of nano-materials } \\
\text { from waste packaging into } \\
\text { the wider environment }\end{array}$ & $\begin{array}{l}\text { Reduced food wastage } \\
\text { reduces depletion of } \\
\text { natural resources }\end{array}$ & As for agriculture \\
\hline & $\begin{array}{l}\text { Future } \\
\text { Generations }\end{array}$ & $\begin{array}{l}\text { Any changes to the } \\
\text { environment incurred } \\
\text { by use of nanotechnology } \\
\text { should be reversible }\end{array}$ & As for agriculture & $\begin{array}{l}\text { Enhanced environmental } \\
\text { protection and food } \\
\text { production and storage } \\
\text { will lead to increases in } \\
\text { quality of life over time }\end{array}$ & As for agriculture \\
\hline Products & $\begin{array}{l}\text { Nano-Product } \\
\text { developer }\end{array}$ & As for agriculture & $\begin{array}{l}\text { To test for and minimise any } \\
\text { potential harm to other } \\
\text { stakeholders from nano-materials } \\
\text { in specific products. } \\
\text { Warn stakeholders of risks } \\
\text { and uncertainties associated } \\
\text { with individual products. }\end{array}$ & As for agriculture & As for agriculture \\
\hline & Farmer & $\begin{array}{l}\text { Freedom to choose } \\
\text { whether to supply } \\
\text { raw materials to } \\
\text { producer of foods } \\
\text { incorporating } \\
\text { nanotechnology. }\end{array}$ & $\begin{array}{l}\text { Responsible use of nano-products } \\
\text { in accordance with regulations } \\
\text { and to avoid harm to animals } \\
\text { or damage to environment } \\
\text { through waste disposal. }\end{array}$ & $\begin{array}{l}\text { Improved profits from } \\
\text { expanded uptake of } \\
\text { products "upstream" } \\
\text { (for example, by retailers } \\
\text { or consumers). }\end{array}$ & $\mathrm{N} / \mathrm{A}$ \\
\hline & Processor & $\begin{array}{l}\text { Freedom to choose } \\
\text { whether, within a } \\
\text { consistent regulatory } \\
\text { framework, to use } \\
\text { nanotechnology in } \\
\text { the development of } \\
\text { food products. }\end{array}$ & $\begin{array}{l}\text { Ensure all products and } \\
\text { processes are rigorously tested. } \\
\text { Avoid use of nanotechnology } \\
\text { in foods that may be suspected } \\
\text { of causing harm to human health } \\
\text { or to the environment. } \\
\text { Provide appropriate labelling } \\
\text { on packaging. }\end{array}$ & $\begin{array}{l}\text { Ability to profit from use } \\
\text { of nanotechnology in } \\
\text { food products and to } \\
\text { develop new products. }\end{array}$ & As for agriculture \\
\hline
\end{tabular}




\begin{tabular}{|c|c|c|c|c|c|}
\hline $\begin{array}{l}\text { Area of } \\
\text { application }\end{array}$ & $\begin{array}{l}\text { Stakeholder/ } \\
\text { Entity }\end{array}$ & Autonomy & Non-malfeasance & Beneficence & Justice \\
\hline & Consumer & $\begin{array}{l}\text { Foods containing } \\
\text { nano-materials or } \\
\text { created using processes } \\
\text { involving nanotechnology } \\
\text { should be clearly labelled } \\
\text { as such. The specific } \\
\text { nano-materials used } \\
\text { should be identified in } \\
\text { order that consumers } \\
\text { can make an informed } \\
\text { purchasing choice. }\end{array}$ & As for agriculture & $\begin{array}{l}\text { Ability to benefit from } \\
\text { better quality, longer } \\
\text { lasting food and greater } \\
\text { more targeted health } \\
\text { and nutrition benefits } \\
\text { without fear of unknown } \\
\text { risks. }\end{array}$ & As for agriculture \\
\hline & Animals & $\mathrm{N} / \mathrm{A}$ & $\begin{array}{l}\text { Use of nanotechnology } \\
\text { in feedstuffs should be } \\
\text { clearly identified do } \\
\text { not inadvertently fed to } \\
\text { animals }\end{array}$ & $\begin{array}{l}\text { Improved and better } \\
\text { targeted health and } \\
\text { nutrition. }\end{array}$ & $\begin{array}{l}\text { Use of nanotechnology in } \\
\text { the production of animal } \\
\text { feeds should be clearly identified. }\end{array}$ \\
\hline & Environment & As for packaging & $\begin{array}{l}\text { Appropriate assessment } \\
\text { of environmental risks and } \\
\text { measures in place to } \\
\text { minimise or eliminate } \\
\text { contamination, bioaccumulation } \\
\text { or leach from animal feed/ } \\
\text { agricultural products or } \\
\text { nanotechnology products } \\
\text { into the wider environment }\end{array}$ & $\begin{array}{l}\text { Improved food security } \\
\text { through more sustainable } \\
\text { production of more } \\
\text { nutritious foods reduces } \\
\text { impact on the environment }\end{array}$ & 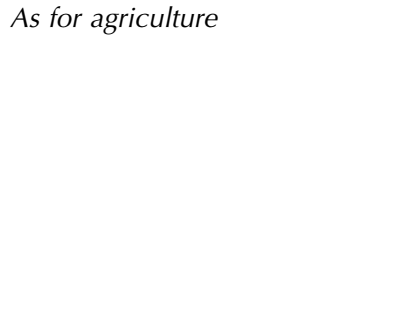 \\
\hline & $\begin{array}{l}\text { Future } \\
\text { Generations }\end{array}$ & As for packaging & As for agriculture & $\begin{array}{l}\text { Nutritionally enhanced food } \\
\text { products and environmental } \\
\text { protection will accumulate } \\
\text { positive effects over time } \\
\text { across generations }\end{array}$ & As for agriculture \\
\hline
\end{tabular}


nanotechnological applications have the potential to achieve many of the claimed benefits, such as improved quality in food products, flavour enhancement and better and more targeted delivery and bioavailability of nutrients. However, potential risks remain which are largely unknown and should be the focus of further research (Singh \& Nalwa, 2007). The ethical principle of autonomy, and the right of the consumer to choose whether they wish to be exposed to unknown potential risks, is raised. The principle of autonomy is the capacity of a rational individual to make an informed, uncoerced decision. For an individual to have the capacity to make an informed decision they first need to be provided with the necessary information. This means being able to assess the risks and benefits (whether real, perceived or unknown) associated with the application of nanotechnology applied. In order for the decision to be uncoerced the individual also needs the capacity to make a choice and indeed be aware that there is a choice to be made. Many developers of nanotechnology applications in food are utilising processes and bringing products to the market without making the consumer aware that nanotechnological processes or substances are involved (Scrinis and Lyons 2007). However, with regard to REACh, that there are several REACh nano-specific requirements which are relevant $^{2}$ (Table 1).

Similarly there appears to be very little information provided to (e.g.), farmers and other agricultural end-users, on the nanotechnology constituents of pesticides or soil enhancement products. Although nano-pesticides might reduce the burden of traditional pesticides on the environment, it is possible that they may create new kinds of contamination of soils and waterways due to enhanced transport, longer persistence and higher toxicity (Kah, Beulke, Tiede, \& Hofmann, 2013). As this potential risk is currently unknown, growers and producers of food can only have autonomy if they have sufficient information for them to make a choice as to whether they wish at the current state of knowledge, to use such products on their land and/or animals. A key issue is that there is no requirement for products derived from nanotechnology, or from processes that involve use of nanotechnology, to be labelled as such. Therefore in most cases consumers and other users may well be unaware of the extent to which nanotechnology is involved in the agriculture and food production system.

Over the last century or so there have been a number of technologies which one might identify as having significantly transformed the food industry or have the potential to do so. These would include inter alia mechanisation, information technology (IT), development and use of polymers (plastics etc.) in packaging and processing and the use of artificial additives in food. Use of mechanisation

\footnotetext{
2 http://ec.europa.eu/environment/chemicals/nanotech/\#reach, (accessed 22nd August 2013).
}

and IT are essentially benign, although they have significantly altered practices in the food and farming industry which has had an impact in other areas such as housing and employment. Use of polymers in packaging in particular has had enormous benefits in terms of lightness, shape, convenience etc. but has also presented a problem in terms of unrecyclable waste, which has only been addressed recently as societal interests in sustainability increases. These innovations were introduced to promote specific benefits with no reference to potential harms. In the case of inorganic artificial additives, potential health risks are recognised and regulation has increased to ensure adequate risk assessment and control if appropriate. It is also a requirement that they be clearly identified in products through mandatory labelling. A similar situation exists for any foods or processes involving or sourced from genetically modified products. Relatively few GM products are licenced for use in the European Union and the great majority of consumers, including many of those willing to consume GM-derived products believe that foods should be labelled to indicate whether GM products are involved in their production (Frewer, Coles, Houdebine, \& Kleter, 2013). Surveys on the use of nanotechnology applications in food indicate that its use in food packaging is assessed by consumers as less problematic than nanotechnology foods themselves. However, perceived control is considered to be an important factor influencing consumer perceptions as is the importance of naturalness. Opposition to or acceptance of nanofood is very much related to trust in governments and the regulatory system (Siegrist, Stampfli, Kastenholz, \& Keller, 2008; Vandermoere, Blanchemanche, Bieberstein, Marette, \& Roosen, 2011)

Use of nanotechnology in the food industry seems to be much closer to artificial food additives and GM than to the other technologies mentioned above. As with artificial additives, nanotechnology involves the introduction of manufactured chemical substances to food and food processes or, like GM technology, causes changes to the characteristics of foods or food sources, in addition to creating the possibility of unknown potential risks to human health, the environment and future generations. This suggests that manufacturers should indicate whether nanotechnology has been involved in the processing or production of their products and in particular whether they contain nanotech ingredients. This would enable the consumer to make an informed autonomous choice, e.g. regarding whether they wished to purchase foodstuffs that had been grown in soils treated with nano-soil enhancers such as carbon nano-tubes or nano-pesticides, products packaged using nano-materials such as nano-silver with uncertain waste disposal characteristics or foodstuffs which themselves contain nanomaterials. Central to informing the consumer is the principle of adequate and appropriate labelling to enable consumers to identify both ingredients and processes related to the production of their food. The advantage to manufacturers is that the use of technology in processing is 


\begin{tabular}{|ll|}
\hline Table 3. Regulations relevant to food labelling. \\
\hline Legislation & Purpose \\
\hline Directive 2000/13/EC & $\begin{array}{l}\text { Governing the labelling, presentation } \\
\text { and advertising of foodstuffs } \\
\text { Amendment relating to labelling } \\
\text { Directive 2001/101/EC }\end{array}$ \\
of meat \\
Directive 2003/89/EC & $\begin{array}{l}\text { Labelling of ingredients present in } \\
\text { foodstuffs }\end{array}$ \\
Novel Foods & $\begin{array}{l}\text { Rules for the authorisation of } \\
\text { nevel foods, ingredients and } \\
\text { Regulation (EC) }\end{array}$ \\
po. 258/97 & processes \\
\hline
\end{tabular}

perceived to be open, and labelling enables consumers to make an informed choice about purchase and, in the case of foodstuffs, consumption.

Labelling of foodstuffs in the EU is currently covered by a number of Directives and Regulations (Table 3).

One or more of these regulatory instruments may need to be amended to take account of use of nanotechnology in food and agriculture. However it will first be necessary to establish an agreed definition of what constitutes "nanotechnology" in relation to its application in foods.

\section{Conclusions}

Nanotechnology applied to food production generally raises many ethical issues, both in relation to the need to develop innovative solutions to emerging challenges (for example, food security or sustainable production) but also in relation to risk assessments in the areas of health, environmental and socio-economic impacts. Analysis also suggests that ethical issues may need to be considered in relation to all actors and stakeholders involved in agrifood nanotechnology, both in terms of how their actions and decisions have impacts elsewhere, and how they are affected by actions and decisions made by others. Central to this is the concept of non-malfeasance, beneficence, autonomy and justice. At present, the European regulatory frameworks which deal with agrifood nanotechnology (including those related to labelling) are rather diverse, and none of these deal with ethical issues focused on agrifood nanotechnology. As a consequence, developers and manufacturers are left with uncertainties regarding legislation relevant to food nanotechnology, for example in relation to riskbenefit assessment, labelling, or ethical production.

\section{Acknowledgements}

The authors would like to acknowledge the EU $7^{\text {th }}$ Framework Programme support of the project FoodMicroSystems through contract number 287634, and Nikki Parker for her help in preparing the manuscript.

\section{References}

Beck, U. (1992). Risk society: Towards a new modernity. London, U.K: Sage.

Boxall, A. B. A., Tiede, K., \& Chaudhry, Q. (2007). Engineered nanomaterials in soils and water: how do they behave and could they pose a risk to human health? Nanomedicine, 2(6), 919-927.
Chaudhry, Q., Castle, L., \& Watkins, R. (2010). Nanotechnologies in foodln RSC nanosciences and nanotechnology No. 14, Cambridge, U.K: RSC Publishing.

DeLorme, M. P., Muro, Y., Arai, T., Banas, D. A., Frame, S. R., Reed, K. L., et al. (2012). Ninety-day inhalation toxicity study with a vapor grown carbon nanofiber in rats. Toxicological Sciences, 128(2), 449-460.

Duncan, T. J. (2011). Applications of nanotechnology in food packaging and food safety: barrier materials, antimicrobials and sensors. Journal of Colloid and Interface Science, 363(1), 1-24.

Ebbesen, M., Andersen, S., \& Besenbacher, F. (2006). Ethics in nanotechnology: starting from scratch? Bulletin of Science, Technology and Society, 26(6), 451-462.

ElAmin, A. (2007). Carbon nanotubes could be new pathogen weapon. Europe: FoodProductionDaily.com. http://www. foodproductiondaily.com/news/ng.asp?id=79393nanotechnologypathogens-ecoli (13 Nov 2008).

Erikkson, P. (1988). Nanofiltration extends the range of membrane filtration. Environmental Progress, 7(1), 58-62.

European Commission. (2008a). Commission recommendation of 07 02/2008 on a code of conduct for responsible nanosciences and nanotechnologies research. Brussels: EC.

European Commission. (2008b). Communication from the Commission to the European Parliament, the Council and the European Economic and Social Committee. Regulatory aspects of nanomaterial's. [SEC(2008) 2036]. Brussels: EC.

European Commission. (2012). Biotechnology. Special Eurobarometer, 341/Wave 73.1, October 2010.

European Food Safety Authority. (2009). The potential risks arising from nanoscience and nanotechnologies on food and feed safety; Scientific Opinion of the Scientific Committee (Question No EFSAQ-2007-124a). The EFSA Journal, 958, 1-39.

Fabrega, J., Luoma, S. N., Tyler, C. R., Galloway, T. S., \& Lead, J. R. (2011). Silver nanoparticles: behaviour and effects in the aquatic environment. Environment International, 37(2), 517-531.

Federici, G., Shaw, B. J., \& Handy, R. D. (2007). Toxicity of titanium dioxide nanoparticles to rainbow trout (Oncorhynchus mykiss): gill injury, oxidative stress, and other physiological effects. Aquatic Toxicology, 84(4), 415-430.

Fischer, A. R. H., van Dijk, H., de Jonge, J., Rowe, G., \& Frewer, L. J. (2012). Attitudes and attitudinal ambivalence change towards nanotechnology applied to food production. Public Understanding of Science, http://dx.doi.org/10.1177/0963662512440220.

Frewer, L. J., Bergmann, K., Brennan, M., Lion, R., Meertens, R., Rowe, G., et al. (2011). Consumer response to novel agri-food technologies: implications for predicting consumer acceptance of emerging food technologies. Trends in Food Science and Technology, 22(8), 442-456.

Frewer, L. J., Coles, D., Houdebine, L. M., \& Kleter, G. A. (2013). Public perceptions of agri-food applications of genetically modified animals - A systematic review (submitted for publication).

Frewer, L. J., Howard, C., \& Shepherd, R. (1997). Public concerns in the United Kingdom about general and specific applications of genetic engineering: risk, benefit, and ethics. Science Technology and Human Values, 22(1), 98-124. http://dx.doi.org/10.1177/ 016224399702200105.

Frewer, L. J., Norde, W., Fisher, A. R. H., \& Kampers, F. W. H. (Eds.), (2011). Nanotechnology in the agrifood sector: Implications for the future. Weinheim, Germany: Wiley-VCH.

Graciela, W. P., \& Qin, W. (2012). Nanotechnology research methods for food and bioproducts. Oxford, U.K: Wiley-Blackwell.

Gupta, N., Fischer, A. R., \& Frewer, L. J. (2012). Socio-psychological determinants of public acceptance of technologies: a review. Public Understanding of Science, 21(7), 782-795.

Gupta, N., Fischer, A. R., van der Lans, I. A., \& Frewer, L. J. (2012). Factors influencing societal response of nanotechnology: an expert 
stakeholder analysis. Journal of Nanoparticle Research, 14(5), $1-15$.

Hoban, T. J. (1997). Consumer acceptance of biotechnology: an international perspective. Nature Biotechnology, 15(3), $232-234$.

Jones, R., \& House of Lords. (2009). Science and Technology Committee, Nanotechnologies and Food, 1st report of session 2009-10, Vol. II. Evidence.

Kah, M., Beulke, S., Tiede, K., \& Hofmann, T. (2013). Nanopesticides: State of knowledge, environmental fate and exposure modelling: Critical reviews of environmental science and technology (in press). http://www.tandfonline.com/doi/abs/10. 1080/10643389.2012.671750.

Karn, B., Kuiken, T., \& Otto, M. (2009). Nanotechnology and in situ remediation: a review of the benefits and potential risks. Environmental Health Perspectives, 117(12), 1813-1831.

Kaufmann, S. H. F. (2005). Novel vaccination strategies. Weinham, Germany: Wiley-VCH.

Kearnes, M. (2006). Chaos and control: Nanotechnology and the politics of emergence, 29, 57-80.

Khan, A. S. (2012). Nanotechnology: Ethical and social implications. Boca Raton, USA: CRC Press.

Klaine, S. J., Alvarez, P. J. J., Batley, G. E., Fernandes, T. F., Handy, R. D., Lyon, D. Y., et al. (September 2008). Nanomaterials in the environment: behavior, fate, bioavailability, and effects. Environmental Toxicology and Chemistry, 27(9), 1825-1851.

Kreyling, W. G., Semmler-Behnke, M., \& Moller, W. (2006). Health implications of nanoparticles. Journal of Nanoparticle Research, 8, 543-562.

Kuswandi, B., Wicaksono, Y., Jayus, J., Abdullah, A., Heng, L., \& Ahmad, M. (2011). Smart packaging: sensors for monitoring of food quality and safety. Sensing and Instrumentation for Food Quality and Safety, 5(3), 137-146.

Kuzma, J., \& Besley, J. C. (2008). Ethics of risk analysis and regulatory review: from bio- to nanotechnology. Nanoethics, 2(2), 149-162.

Leroueil, P. R., Hong, S., Mecke, A., Baker, J. R., Orr, B. G., \& Banaszak-Holl, M. M. (2007). Nanoparticle interaction with biological membranes: does nanotechnology present a Janus face? Accounts of Chemical Research, 40(5), 335-342.

Lyons, K., \& Scrinis, G. (2009). Under the regulatory radar? Nanotechnologies and their impacts for Rural Australia. In F. Merlan, \& D. Raftery (Eds.), Tracking rural change: Community, policy and technology in Australia, New Zealand and Europe (pp. 151-172). Canberra, Australia.: ANU E Press, (chap. 8).

Maillard, J.-Y., \& Hartemann, P. (2012). Silver as an antimicrobial: facts and gaps in knowledge. Critical Reviews in Microbiology, http://dx.doi.org/10.3109/1040841X.2012.713323.

Mehta, M. D. (2004). From biotechnology to nanotechnology: what can we learn from earlier technologies? Bulletin of Science, Technology and Society, 24(1), 34-39.

Mepham, B. (2000). A framework for the ethical analysis of novel foods: the ethical matrix. Journal of Agricultural and Environmental Ethics, 12(2), 165-176.

Nguyen, D. N., Ngo, T. T., \& Nguyen, Q. L. (2012). Highly sensitive fluorescence resonance energy transfer (FRET)-based nanosensor for rapid detection of clenbuterol. Advances in Natural Sciences: Nanoscience and Nanotechnology, 3(3), 035011.

Nielsen, K. N., Fredriksen, B. N., \& Myhr, A. I. (2011). Mapping uncertainties in the upstream: the case of PLGA nanoparticles in salmon vaccines. Nanoethics, 5, 57-71.

Norde, W. (2011). Introduction. In L. J. Frewer, W. Norde, A. R. H. Fisher, \& F. W. H. Kampers (Eds.), Nanotechnology in the agrifood sector: Implications for the future. Weinham, Germany: Wiley-VCH.

Oberdörster, G. (2010). Safety assessment for nanotechnology and nanomedicine: concepts of nanotoxicology. Journal of Internal Medicine, 267(1), 89-105.
O'Brien, N., \& Cummins, E. (2008). Recent developments in nanotechnology and risk assessment strategies for addressing public and environmental health concerns. Human and Ecological Risk Assessment: An International Journal, 14(3), 568-592.

Pandey, R., Ahmad, Z., Sharma, S., \& Khuller, G. K. (2005). Nanoencapsulation of azole antifungals: potential applications to improve oral drug delivery. International Journal of Pharmaceutics, 301(1), 268-276.

Penyala, N. R., Pena-Mendez, E. M., \& Havel, J. (2008). Silver or silver nanoparticles: a hazardous threat to the environment and human health? Journal of Applied Biomedicine, 6, 117-129.

Poland, C. A., Duffin, R., Kinloch, I., Maynard, A., Wallace, W. A. H. Seaton, A., et al. (2008). Carbon nanotubes introduced into the abdominal cavity of mice show asbestos-like pathogenicity in a pilot study. Nature Nanotechnology, 3, 423-428.

Pronk, M. E. J., Wijnhoven, S. W. P., Bleeker, E. A. J., Heugens, E. H. W. Peijnenburg, W. J. G. M., Luttik, R., et al. (2009). Nanomaterials under REACH: Nanosilver as a case study - RIVM report 601780003/2009. Bilthoven, the Netherlands: RIVM.

Rai, M., \& Ingle, A. (2012). Role of nanotechnology in agriculture with special reference to management of insect pests. Applied Microbiology and Biotechnology, 94(2), 287-293.

Rogers-Brown, J. B., Shearer, C., \& Harthorn, B. H. (2011). From biotech to nanotech: public debates about technological modification of food. Environment and Society: Advances in Research, 2(1), 149-169.

Ryman-Rasmussen, J. P., Cesta, M. F., Brody, A. R., ShipleyPhillips, J. K., Everitt, J. I., Tewksbury, E. W., et al. (2009). Inhaled carbon nanotubes reach the subpleural tissue in mice. Nature Nanotechnology, 4, 747-751.

Satterfield, T., Kandlikar, M., Beaudrie, C. E. H., Conti, J., \& Herr Harthorn, B. (2009). Anticipating the perceived risk of nanotechnologies. Nature Nanotechnology, 4, 752-758.

Schroeder, D., \& Palmer, C. (2003). POIESIS \& PRAXIS. International Journal of Technology Assessment and Ethics of Science, 1(4), 295-307.

Scrinis, G., \& Lyons, K. (December 2007). The emerging nanocorporate paradigm: nanotechnology and the transformation of nature, food and agri-food systems. International Journal of Sociology of Food and Agriculture, 15(2).

Sekhon, B. S. (2010). Food nanotechnology - an overview. Nanotechnology Science and Applications, 3(1), 1-15.

Siegrist, M., Cousin, M. E., Kastenholz, H., \& Wiek, A. (2007). Public acceptance of nanotechnology foods and food packaging: the influence of affect and trust. Appetite, 49(2), 459-466.

Siegrist, M., Stampfli, N., Kastenholz, H., \& Keller, C. (2008). Perceived risks and perceived benefits of different nanotechnology foods and nanotechnology food packaging. Appetite, 51(2), 283-290.

Singh, S., \& Nalwa, H. S. (2007). Nanotechnology and health safety toxicity and risk assessments of nanostructured materials on human health. Journal of Nanoscience and Nanotechnology, 7(9), 3048-3070.

Sozer, N., \& Kokini, J. L. (2009). Nanotechnology and its applications in the food sector. Trends in Biotechnology, 27(2), 82-89.

Tepper, et al., Inventors, (Jan 2005). Nanosize Electropositive Fibrous Adsorbent, US Patent No. 6,838,005 B2.

Vandermoere, F., Blanchemanche, S., Bieberstein, A., Marette, S., \& Roosen, J. (2011). The public understanding of nanotechnology in the food domain: the hidden role of views on science, technology and nature. Public Understanding of Science, 20(2), 195-206.

Wang, Z., Zhao, J., Lei Song, L., Mashayekhi, H., Chefetz, B., \& Xing, B. (2011). Adsorption and desorption of phenanthrene on carbon nanotubes in simulated gastrointestinal fluids. Environmental Science Technology, 45(14), 6018-6024.

Wang, J. X., Zhu, X. S., Zhang, X. Z., Zhao, Z., \& Liu, H. A. (2011). Disruption of zebrafish (Daniorerio) reproduction upon chronic exposure to $\mathrm{TiO}_{2}$ nanoparticles. Chemosphere, 83, 461-467. 